Featured Essay

\title{
The Dialectics of Power, Rights, and Responsibility ${ }^{1}$
}

Ranhilio Callangan Aquino

\section{By way of introduction}

$\mathrm{I}$

$\mathrm{t}$ is not uncommon for a treatment of rights to be treatment against power with some concession to the responsibilities that a tutelary of rights enjoys. We owe it to legal philosophers of the Scholastic persuasion who recognized rights as the entitlements that allow a person to fulfill dutieswhether these arise from nature or from contract. In this sense rights were subordinate to and enjoyed for the sake of duties that one had. One may debate this way of putting things, but it had the marked advantage of clarity and showed the internal connection between rights and duties. Also in the scholastic anatomy of rights, there was such a thing as the "term" of the right - he against whom the right could be claimed, and therefore he or she upon whom a duty was incumbent to desist from transgressing the right of the tutelary. In this sense a "right to" was concomitantly "power against," but power, in the sense of claim or entitlement. For the power to enforce, one had to look to what scholastic philosophers called the "title" of the right—and this could be natural law, positive law that, of course, included contracts.

I do not think that this was bad at all, but I would like to pick up the subject today by paying attention to two leading figures: Paul Ricoeur and Jürgen Habermas.

\section{Ricoeur}

It is said with good reason that Ricoeur's focus, in his later works, was the "capable person." But as acting and speaking, a person is also subject to precepts. He is accessible to precepts. The vexatious dichotomy between "ought" and "is" therefore does not arise, for Ricoeur, in respect to the person, because the very "is" of his actions comes with the "ought" of precepts. ${ }^{2}$

Admitting that there is no philosophical necessity for distinguishing between ethics and morals, he nevertheless introduces an ad hoc distinction.

1 This paper was read at the 2008 Annual Philosophy Day Conference sponsored by the UNESCO National Commission of the Philippines held at the Ateneo de Manila University on November 20, 2008.

2 Paul Ricoeur, Oneself as Another (Chicago: The University of Chicago Press, 1992), 169. 


\section{THE DIALECTICS OF POWER}

Ethics refers to the aim of an accomplished life, and morality, the articulation of this aim in norms characterized by the claim of universality and by an effect of constraint. And the ethical intention is "aiming at the good life with and for others in just institutions.

Now practice, whether it be the practice of a profession, of an art or of conduct is unified by the dimension of meaning in which it makes sense to evaluate, and therefore to refer to norms and to the precepts of doing something. Writing this paper is reading books, writing lines, re-writing them, exchanging views with others - all of which have meaning because of the standard of a philosophy paper by which one can evaluate whether it is a carefully thought out paper or not. Standards, however, are never the fruit of the ruminations of the solitary actor, performer or agent, but of a community or society of practitioners. ${ }^{3}$

From this level of appreciating the capable person, it is clear that basic power is the power to evaluate both his own actions and those of others in accordance with the standards of excellence that serve as constitutive rules. In another work, Ricoeur asks more directly about the "subject of rights." This ethical question culminates in the proposition of philosophical anthropology that the subject of rights is the capable subject who is capable of assignment, by which he means the capacity of the human subject to designate himself as author of the acts. And we are worthy of esteem and respect - which is a way of talking about our rights - insofar as we are able to esteem as good or bad, declare as permitted or forbidden, actions of others or of ourselves. A subject of imputation therefore results from the reflexive application to agents of the predicates like "good" or "obligatory."

The persons' basic power-his capacity for assignment (or assignation) is his power to esteem, and therefore also his entitlement also to esteem and respect. On this level, the capable person's power is at the basis of his rights, but this is not the power to claim rights, nor to enforce them against others, but principally the power to use the qualifiers good or bad in respect to his own actions and those of others, at the same time as he attributes or assigns these actions to himself.

But still following the development of Ricoeur's ethics, we meet with another, though not unrelated, face of power: The power to engage in praxis whose teleology he can nest within his greater life-plan. Obviously, power can be visited upon a person to engage in praxis that resists coherent integration into his life-plan, and that constitutes the basic violation of the human person. ${ }^{5}$

So what is the good life? It is the nebulous of ideals and dreams of achievement with regard to which a life is held to be more or less fulfilled or unfulfilled. It is that in view of which all actions are directed, though these actions may have ends in themselves. Getting to meet you and discuss power and rights with you today is an end in itself, but to deal with the good life, this

\footnotetext{
${ }^{3}$ Ibid., 176.

${ }^{4}$ Paul Ricoeur, The Just (Chicago: The University of Chicago Press, 2000), 3-4.

${ }^{5}$ Ricouer, Oneself as Another, 179.
} 
finality must somehow be orientated towards what I take-never monadically of course- to be a fulfilled life.

There must perforce be constant reference back to our notions of the good life in commencing that praxis that may have end in itself, just as take the cue for actions in which we engage from our notion of the good life. Lifeplans and praxis are therefore to be interpreted by constant reference to each other. Action is therefore interpreted, and the person who interprets his actions must in the same measure interpret himself.

Solicitude is Ricoeur's term for the good life with and for others. It is not an added moment to self-esteem but is essential to it. The path to mineness (esteem for myself) traverses the unexpressed reference to the other. To esteem what I have written is to be confident that an exchange with you can only be fruitful, not threatening.

Life can be good only with friends. Hence at the heart of the aim at the good life is a "lack": we need friends, and "need" not be a term of utilitarian monopoly. In fact, Ricoeur puts it very well: "Need has to do not only with that which is active and incomplete in living together but also with the sort of shortage or lack belonging to the very relation of the self to its own existence." There is lack therefore that dwells in the most solid of friendships. ${ }^{6}$

Ricoeur makes the very pointed observation that in many languages, goodness is the ethical quality of the aims of action and the orientation of the person towards others. An action is not held as good unless it is done on behalf of others, where mabuti bears reference not only to what a person does, but to what he does in behalf of others, or for the sake of others, thus distinguishing mabuti from mahusay or magaling. Solicitude is benevolent spontaneity. I adjudge care and concern for others good, and myself as good insofar as I am truly solicitous. ${ }^{7}$

For Levinas, the Other appears as the master of justice, the preceptor of the right, the embodied prohibition against murder. The Otherness of the other precisely defines exteriority and thus excludes relation. This asymmetry is compensated by benevolence, through the movement of recognition. But the inverse situation is also the appearance of the other in suffering: suffering will not be confined to physical pain, or even mental pain, but by reduction even the destruction of the capacity for acting, for being able to act, experienced as a violation of self-integrity.

This gives us the negative side of power: It is within my power to cause the other to suffer, principally in violating the other's self-integrity. The exercise of this kind of destructive power, which I shall call violence, is the very negation of the right of the other, which I also understand as the magisterial or instructive position of the other. It is the antithesis of the benevolent spontaneity that is solicitude.

But this also allows us into another important dimension of the power of the human person: the power to receive the pain and anguish, the suffering

\footnotetext{
${ }^{6}$ Ibid., 181-186.

${ }^{7}$ Ibid., 190.
} 


\section{THE DIALECTICS OF POWER}

and distress of the one who has less power (or is even powerless). It is the capacity of sympathy which is the heightened for of the capacity for solicitude. In this regard, all effort to balance talk of power and rights with attention to responsibilities is superfluous. The power that we here encounter is the power of responsibility - in the sense of responding not with pity but with sympathy to the plight of the other. It is the power for the subservience of power to the weakened condition of the other.

Once more, however, we must advert to the execrable form of the use of power-and that is when power is directed against the power of the solicitous and sympathetic person. The most dramatic examples of this terrible brutalizing use of power come to us from those movie clips of Nazi prisoners tasked to dig the graves of their own relatives and friends and to toss them nonchalantly like garbage into a common pit, or to shove them into a crematorium. The power each of those hapless prisoners had to sympathize with the victims - totally stripped of all power-was suppressed, stifled, shacked by the overpowering power of brute force or strategic advantage and superiority, so that one just dug, picked up bodies, even if they were the bodies of loved ones once cuddled and caressed, without any emotion. This is the power directed against the very heart of the ethical, and therefore the most unethical use of power, but it is the power that attempts at canceling solicitude and sympathy that are at the very heart of the aspiration to live a good life with others.

Between the extremes of summons by the Other from a magisterial height that always excludes relations (Levinas) and the spontaneity of sympathy at the immense suffering of the other is friendship where the self and the other wish to share the same life together. The presupposed equality of friendships is re-established by the acknowledgment of the superiority of the other who calls, and in sympathy, by shared agony, vulnerability and fragility. To selfesteem in its reflexive moment friendship adds the dimension of lack-we need friends, and a sense of equality: I am, with friends, an equal to them. ${ }^{8}$

The recognition of right must of necessity be part of the ethical moment, because the consequence of the denial of rights is the denial of equality. While it is true that there is something aristocratic about friendship (it does not extend to all), to wish for the good life with others cannot mean excluding the others from the good life, or excluding anyone a priori from the circle of friends form whom I am solicitous. Responsibility is my susceptibility to summons; it is at the same time the essence of solicitude that must first of all recognize the equality of the other, my equality with him, and thus a basic recognition of right. The misuse or abuse of power is precisely the perversion of sympathy because it exploits the vulnerability of the other, where sympathy shares in weakness and anguish.

The last item in Ricoeur's analysis is "just institutions," for the transformation of the veritable subject of rights into an actual subject of rights does not take place without the mediation of the Other, and the other is not

8 Ricouer, Oneself as Another, 192. 
encountered only in the dialogical and in the intimate, but also in the anonymity of the third person. Interpersonal relations do not exhaust the whole gamut of living together that will include communities, societies, nations. ${ }^{9}$

There is a will to live together. The ethical aim includes this will. "The golod life in unjust institutions" is incomprehensible. It is incoherent. Ricoeur borrows from Arendt the notion of "power in common" to deal with plurality which extends to all others whom I do not encounter face to face and are therefore third persons. A plea for the anonymous is therefore part of the ethical life.

For Arendt, the space of appearance comes into being whenever persons are together in the manner of speech and action. This space is prior to the state, prior to organized polity. It exists for as long as persons are together and act together; it ceases when they disperse. ${ }^{10}$ Political communities are killed first by loss of power and then impotence. Power is never stored up so that it may tapped in times of crises. There is no such thing as stored power, only power in actu. It exists only in its exercise, in its actualization. "Power is actualized only where word and deed have not parted company, where words are not empty and deeds are not brutal, where words are not used to veil intentions but to disclose realities, and deeds are not used to violate and destroy, but to establish relation and create new realities."11

Arendt therefore contrasts power and force. Force is that which is employed by those who have cornered the means of violence (despots, aristocrats, even rebel groups as well as the lords of society's netherworlds) for themselves. While violence can destroy power, it can never substitute for it. So it is that there then can co-exist force and powerlessness, the impotent spent force of futile impositions. Arendt therefore reaches a spectacular conclusion, inspired, she admits by Montesquieu: Tyranny is not a form of government but the very antithesis of plurality, because the tyrant thrives by isolating himself from the people and by isolating people from each other. Tyranny then breeds the germ of its own destruction the moment it makes its appearance because it is unable to sustain the power to remain in the public space of appearance. ${ }^{12}$

Power is therefore fundamentally wanting to act and to live together and thus does not have to be forced to submit to ethical precepts. It is part of the ethical aim to live a good life with others in just institutions. This brings justice into the picture, and it has two faces: the 'good' that extends interpersonal relations to institutions, and the 'legal' whereby the judicial system gives law coherence and society, constraint. ${ }^{13}$

${ }^{9}$ Ricouer, The Just, 5.

${ }^{10}$ Hannah Arendt, The Human Condition (Chicago: The University of Chicago Press, 1958), 199.

${ }^{11}$ Ibid., 200

${ }^{12}$ Ibid., 202.

${ }^{13}$ Ricouer, Oneself as Another, 197. 


\section{THE DIALECTICS OF POWER}

Power from this perspective is the guarantor of right, not principally in the sense than an armed sector of society polices against violators of right, but in the sense that what allows for justice-the extension of the interpersonal to institutions and the coherence and restraint of legal systems (including constraints to legal behavior and restraints against violations of rights) - is the will to live together, action or power in common. The 'will to live together' must also be an elemental form of responsibility, but this cannot be other than a dimension of the ethical aim of living a good life with others in just institutions.

\section{Habermas}

Law plays today the role of archaic institutions and a seamless, undisturbed, uncolonized life-world in the past. Archaic institutions are just that-surpassed by the post-conventional, and the life-world is increasingly rationalized and therefore subject to the ravages of unrelenting pluralism. But with law and its role of lending society coherence and stabilizing behavior expectations, there arises the tension of its facticity-want it or not, it is there, it is a social fact-and its validity-whether or not in commands obedience and allegiance, whether or not it justifies the employment of the coercive power of the State.

Legitimate law and coercion can co-exist without antagonism for Habermas, but this can be so only if legal coercion does not destroy the rational motive for obeying the law. While unanimity is not demanded, what must at all times be possible is for all those affected by the law "to grasp the point," to obey on the basis of insight, on the basis of rational grounds. Precisely because law must leave addressees free to accept or to contest, then it must also leave them free to take the posture of "objectivation": I really do not care much about the law, but it is better to comply than to be penalized.14

The basic rights that Habermas identifies are not rights against the State as such bu more fundamentally consequences of the discourse principle: allowing only such actions norms to count as valid as can meet with the approval of all potentially affected participating as consociates in rational discourse. That there will be, unfortunately, members of society who refuse to accept rational argument, who employ strategic force in place of participating the public sphere of opinion and will-formation is the very reason that the State must wield coercive power. The basic rights of which Habermas rights regulate the relations among freely associated citizens and are therefore prior to any legally organized state authority against whose encroachments citizens may claim rights. With the right to participate in those processes by which legitimate law is generated, citizens become authors of the law. ${ }^{15}$

\footnotetext{
${ }^{14}$ Jürgen Habermas, Between Facts and Norms: Contributions to a Discourse Theory of Law (Massachusetts: The MIT Press, 1998), 120-121.

${ }^{15}$ Ibid., 123.
} 
As legal subjects, persons are given a code within which their autonomy is to be actualized. Human autonomy is autonomy within the space of law. Persons therefore understand themselves as authors of the very rights to which they all submit, but all this within the context of self-legislation that occurs within - not outside-the medium of law itself. It is persons who debate that which legislatures codify as legal rights. More than this, citizens can determine for themselves whether the laws they pass are legitimate through the freedom to participate in basic political processes that form the legislators' will and opinion.

The right of equal participation results from the juridification of the communicative freedom of all citizens. Communicative freedom is the power of unrestrained communication, exchange and will formation to generate rationally motivated consensus. Seen this way, popular sovereignty and human rights go hand in hand, and civic and private autonomy are co-original. ${ }^{16}$

But Habermas has grander plan: the reconstruction of law by which he means discovering the conditions under which modern legal and political orders count as legitimate.

The abstract rights of persons become concrete and enforceable through democratic and discursive law making. The power of the law is essentially the power of rationally motivated consensus, and therefore ultimately, the power of communicative action that Habermas contrasts starkly with the strategic use of power. In his reconstructive theory, Habermas first develops a theory of a system of rights, and then articulates the principles of the constitutional state, by which these rights are secured through law. ${ }^{17}$

This is one level of the encounter between power and rights. On this level, one calls on communicative power that is juris-generative to translate the realm of abstract rights into a regime of legally enforceable rights. It also becomes apparent that the most elemental right is the right to participate as consociate in discourse that generates law, that communicative action that later on becomes structured-vertically_as legislative discourse. Rights and democracy are therefore co-equal in the idea of legitimate law.

As for the constitutional state, a central principle of constitutionalism the reciprocal link between law and political power. This is a second-level encounter with power. Institutions for applying law are state-organized and the legal decisions of such institution are enforced through coercive statepower. From one side, political power is legitimate only when exercised in legal form and according to legal procedures. In this sense, law legitimates the exercise of political power. Law and political power therefore presuppose each other. But for law-making to be democratic, something else is necessary and for this Habermas enunciates the discourse principle. Applied to the engenderment of law, it is the democratic principle and it demands that 'only

${ }^{16}$ Ibid., 127

17 Hugh Baxter, "System and Lifeworld in Habermas' Theory of Law", Cardozo Law Review 23:2 (2002), 477-615 at 483. 


\section{THE DIALECTICS OF POWER}

those laws may claim legitimacy that can meet with the assent of all citizens in a discursive process of legislation that in turn has been legally constituted.'

Some have despaired, without reason to my mind, over what they perceive to be the impossibly stringent demands of this principle. I do not read it as requiring the impossible. In the first place, it does not require unanimity. It merely requires that the legislature be prepared with such arguments for the law as may meet with the rationally motivated acceptance of reasonable persons. Second, it does not require that all citizens legislate. It only requires that the will formation of citizens be taken up by the discursive process of legislation that is itself legitimately constituted.

Responsibility and communicative power demand each other. Communicative power is that power that responsible consociates wield by communication that ensures that all relevant questions, issues and contributions are brought up and processed in discourses and negotiations on the basis of the best available information and argument. ${ }^{18}$ This entails the responsibility to advance arguments, the responsibility to raise crucial and critical questions and the responsibility to yield to the force of the better argument.

There is, therefore, much to commend in what Habermas calls in another work "the moral principle" which is actually the articulation of a form of responsibility - an elemental form. Each participant to practical discourse must transfer his subjective desires into generalizable desires. Precisely because Habermas insists that all claims must be redeemed by the responsible speaker or actor, then in a sense even this requirement is superfluous because only such claims are within redemption that advance generalizable interests with which consociates can identify. In fact the basic responsibility is the responsibility to justify and to redeem one's claims in terms and arguments comprehensible to all possibly affected. ${ }^{19}$

$$
\begin{array}{r}
\text { Graduate School of Law, San Beda College, Philippines } \\
\text { Department of Jurisprudence and Philosophy, Philippine Judicial Academy, } \\
\text { Supreme Court of the Philippines, Philippines }
\end{array}
$$

\section{References}

Arendt, Hannah, The Human Condition (Chicago: The University of Chicago Press, 1958).

Baxter, Hugh, "System and Lifeworld in Habermas' Theory of Law," Cardozo Law Review, 23:2 (2002), 477-615.

Habermas, Jürgen, Between Facts and Norms: Contributions to a Discourse Theory of Law (Massachusetts: The MIT Press, 1998).

Habermas, Jürgen, Legitimation Crisis (Boston: Beacon Press, 1973).

\footnotetext{
18 Habermas, Between Facts and Nroms, 170.

${ }^{19}$ Jürgen Habermas, Legitimation Crisis (Boston: Beacon Press, 1973), 107-108.
} 
Ricoeur, Paul, Oneself as Another (Chicago: The University of Chicago Press, 1992).

Ricoeur, Paul, The Just (Chicago: The University of Chicago Press, 2000). 